\title{
"This Rough Magic I Here Abjure" Performativity, Practice and Purpose of the Bizarre
}

\author{
Brian Jay Corrigan \\ University of North Georgia
}

\begin{abstract}
This paper argues that through the theatrical application of defamiliarization (ostranenie) the performer of 'bizarre' magic seeks to achieve an 'illusion of reality' which transcends the traditional performance-magic desire to deceive and rather create a long-lasting impression in the minds of the spectator that artistically confabulates, instilling a realistic memory spawned of a pretended reality. The article distinguishes 'presentational' from 'representational' theatrical approaches to argue that the 'bizarre' magician performs within a hyper-representational mode that the author terms 'paratheatre', meaning theatre and performance that the audience fails to recognize as such. Tracing the history of magic from its application among, inter alia, the priestly classes through stage magicians, this article discusses the 'bizarrist' aim to remove magic from the expectation of deception and any willing suspension of disbelief, and, via convincing storytelling, re-situate the magic moment into an atmosphere of genuine acceptance and even belief.
\end{abstract}

\section{KEYWORDS}

Bizarre Magic, Bizarrist, History of Performance Magic, Robert-Houdin, Maskeleyne, Vaudeville, Illusion of Reality, Defamiliarization 
Entertainment is always about the audience's emotions. A good circus act thrills. A good tragedy elicits tears. A good magic act should spark wonder. Like a fairytale come to life, magic should raise those primal hopes and fears that whisper in the subconscious, those inklings that suggest, just perhaps, we are not alone in the darkness. Bizarre magic seeks to recapture the fascination every human being has as a child that creatures may indeed dance in the midnight meadow or rise from the churchyard after the Compline bell has rung.

Bizarre magic seeks to create in performance the socio-psychological response that creates (or can create) personal epiphany in its audience. By eschewing the purely-for-entertainment approach of the traditional magician, Bizarre seeks to forge a more profound impact upon its viewer by means of employing traditional notions of defamiliarity, which is the art of presenting something commonplace as exceptional or strange, thereby seeking to strip mystery entertainment of the stigma of 'tricks' and 'fooling' and restore a genuine sense of wonder to magic.

In its aims and approaches, Bizarre magic seeks to replicate the reaction audiences once had to Christopher Marlowe's Tragical History of the Life and Death of Doctor Faustus. The sixteenth-century audience who witnessed the chanting of fake spells to raise mock demons could never be entirely certain that what they witnessed was not, at least potentially, genuine. Most of the audience were sophisticated enough to know that they were in the presence of a theatrical presentation, but there was also just enough of superstition in their culture still to create the vague worry that the pretended spells of the actor might accidentally transect the actual line dividing them from satanic forces. This uncertainty was so strong, in fact, that Edward Alleyn himself, the actor who originated and performed the part of Faustus for decades, ultimately retired to found Dulwich college in which he also endowed a stipend to pay for daily prayers 'in perpetuity' to save his soul, for he feared that his performances may have caught the attention of infernal beings. Unlike the earliest dramas wherein supernatural phenomena were taken as metaphorical expressions of natural powers, Marlowe directly confronted his audience (and actors) with their own secret fears, presenting superstition as fact. As such, Marlowe created in Faustus the very goal that Bizarre magic seeks to attain: a demonstration that cultural fears and arcane knowledge may indeed be founded upon fact.

In a similar vein, Jean-Eugéne Robert-Houdin's automata and John Nevil Maskelyne's inventions at the Egyptian Hall represent an evolution towards the modern concept of Bizarre magic. In both Robert-Houdin and Maskelyne 
one can discern a movement of magic beyond entertaining trickery and into the realm of supposed reality. These magicians revealed their automated wonders just as machines began to grow in the public's awareness. The fact that machines were replacing human beings in the workplace caused many to worry that humanity itself was on the wane; meantime, these magical machines, whether genuine or faux in their workings, played upon these very modern-world superstitions. These machines (endued with apparently magical abilities) could replicate and even improve upon the very foundations of humanity. These were artistic machines that could create music, paint, draw or dance upon a trapeze as well as thinking machines that could challenge the finest chess players and win. Mechanization was the new witchcraft, and these magicians played upon the cultural fears that machinery represented - at once delighting and vaguely horrifying their audiences with the quasi-supernatural powers which they could apparently summon with springs and gears.

Similarly, a mere quirk of wording on October 30, 1938 produced what might be called the bizarrist's effect. Americans tuning into the evening radio were alerted to an invasion from Mars. Amateur magician and soon-to-be legendary auteur Orson Welles became famous when he convinced a nation that an extraterrestrial landing had occurred in Grover's Mill, New Jersey, striking genuine panic into the hearts of a nation. Welles had employed the simple expedient of imitating a genuine news interruption. His audience, primed by the events of the late-1930s to expect news of an invasion in Europe, believed their worst fears were being realized and Germany had surprised the eastern coast of America. Their belief thus wholly engaged, Welles took the short step of substituting Martians for Nazis, and he raised in his listeners' hearts the primal fear of the prey animal. The Faustus demons were now space aliens, but the emotional response was identical: this might be real. Such emotion and belief is the aim of the modern-day bizarrist.

Bizarre magic has laboured under the perception (sometimes fostered by its own proponents) that it is a quasi-satanic organisation with only a tangential relationship to traditional performance magic. Proponents of this approach go so far sometimes as to parade about in fancy dress, playing their part incessantly until one genuinely worries over the performer's sanity. This tactic of peculiar pretense, posing as a necromancer, zombie, ghoul, vampire, et cetera, until one almost believes oneself to be so in fact, may sacrifice a normal life and limit one's 'real world' job prospects, but it does successfully disturb and disrupt an audience into that Faustian fear and cause them to wonder whether they are (or may be) in the presence of bona fide alternate-world reality. 
On the other end of the perceptual spectrum, Bizarre magic has suffered under the presumption that it is the art of long-winded storytelling enfolding a rather dreary, traditional trick. Poorly performed, this perception too often becomes an accurate one. A good bizarrist should be able to hold his audience, as Orson Welles did, with the story alone, well-told and effectively presented with significantly genuine-seeming elements, such as Welles' simulated news broadcast. Success requires precise scripting and advanced acting technique. Because, in this case, the story carries the weight of the performance, the magic itself need not require much more than an occurrence that cannot readily be explained beyond the created reality of the tale. The impossible ring of an isolated bell would be enough to raise the Faustian fear sought by the bizarrist. Such a bell would, by necessity, have to be a clever mechanism, as presented in the day of Robert-Houdin or Maskelyne, properly made up to appear no mechanism at all but a simple bell. Done properly, a good bizarre act need not have many tricks in it. When one thinks of the tales of ancient wonders, the Indian Rope Trick for example, they are always tales of a single marvelous event. No additional miracles need apply. A second impossibility would in fact diminish the impact of the first, a third would cheapen the whole, but a fourth, a fifth and a sixth would simply bore, for (as Aesop insists) familiarity breeds contempt. 'When everyone is somebody,' W.S. Gilbert writes in The Gondoliers, 'then no one's anybody', and the same applies to magic: when every moment's a miracle, magic becomes the 'new normal' and loses its impact as something splendid. A bizarre act therefore has no need of, and should in fact shun, the customary cavalcade of effects. It requires, rather, a story that enthralls and makes the audience focus properly on the importance (and wonder) of what could possibly happen.

For such a performance, ambience is everything-the setting of the proper mood and teasing out the required emotional receptivity - and thus the trick is secondary, perhaps even tertiary, to the bizarre tale, presented in its appropriate light. The fundamental desire in bizarre is changed from trickery (the desire to fool an audience) into exploration (the human need to investigate the everlasting appeal of mystery). The magician of the bizarre world wishes to lead groups to the depths of Loch Ness or the snow-swept steep of the Himalayas to point them to the Loch Ness Monster or the Yeti. Hampered by distance, he instead brings a tiny bit of that mystery to his audience in the shape of some ancient marvel, some artifact that might have been drawn directly from the pages of a story by Le Fanu or M. R. James. Thus primed, the audience is excited to imagine that the Great Unseen Forces of lore and legend are in fact true; the bizarrist proceeds to show them a discrete proof that asks more 
questions than it answers: Do ghosts exist? Is there a realm where fairies dance? Does the foot of the garden open into worlds of dark mystery?

The smug twenty-first century answer to these questions, of course, is 'No,' and it is such little-mindedness that the bizarrist seeks to disrupt, for it denies the possibility of something greater than Self. Bizarre magic takes as part of its unspoken philosophy a certainty that there is only misfortunate in a society that believes itself at the zenith of all creation-that there is truly nothing beyond mobile telephones, $4 \mathrm{~K}$ televisions, infomercials, and managing one's credit score. To move forward, says the bizarrist, the human mind must dream, to dream it must imagine, to imagine it must exercise its sense of wonder. To achieve wonderment, it must be shaken from complacency. Faustian fear can certainly do the shaking, and that is the goal of the bizarre entertainer.

Here is a piece of history, the bizarrist tells his audience. It may be a GI's dog tag from the beach at Normandy, a little girl's locket from 1911, Victorian toe tags, an eviscerated pocket watch, elderly first-edition books, a small purse of antique coins, or a disturbing relic from a long-forgotten church in the Pyrenees. This thing is interesting in itself, lovely to look at and hold; just as the automata of Robert-Houdin, this is real and quite certainly atmospheric, but it also has a story attached, and more: it manifests its own living personality before the audience's astonished eyes. This ceases to be 'magic' in the Saturdaymatinee or pub-bet sense of the word, which drives hard towards the alakazam moment only to melt into the supercilious smile of the trickster. Rather, this is history, poetry, antiquity, and human achievement wrapped into an appealing entertainment, an entertainment that at once engages and elicits that precious sense of Otherworldly wonder. Folklore lives, demons laugh, legendary creatures ride the moon's watery beams, and every grave lets forth its sprite, in the church-way paths to glide... following darkness like a dream. It is a most agreeable way to pass an evening.

In every magic trick there is an illogical moment: Why tear up paper merely to put it back together again? Such power is pointless. And, here again, if one can turn five-pound notes into fifty-pound notes, why show it to others? Such magic is illogical. This is one reason that card tricks are popular. People own cards, carry cards, shuffle them, look at them; the logic is generally good with a card trick-you take one; I'll tell you what it is. The illogic comes in the sometimes elaborate handling that occurs before the 'big moment': that I'll-justput-these-behind-my-back-for-a-second operation that (in one way or another) occurs in even the more logical magical set-ups. One problem with the card trick, from a bizarrist perspective, is that it lacks purpose. Is the finding of a 
selected card meant to demonstrate psychic ability, perceptive alteration, or some form of adaptive touch-sense? Depressingly, in most magician's hands, a card trick does nothing beyond demonstrate cleverness culminating in an Itricked-you smirk that both amuses and annoys in equal measure.

One of the primary goals of the bizarrist is to avoid the illogic of magic 'tricks' and create an internal reality within the atmosphere surrounding the performance of an effect. Internal reality in a magic trick is akin to subtext for an actor or novelist. It is, in the words of Charles Baxter, "the implied, the halfvisible, and the unspoken" truth within that suggests authenticity:

In this context the word "haunted" is probably apt. Our most haunting dreams, no matter how hallucinatory, are the most busily etched. The details themselves signal belief-weight, the gravity of a vision that cannot be shrugged off-think of the hyperdetailing in Hieronymus Bosch's The Garden of Earthly Delights, to take one example from visual art. That table in a nightmare comes complete with a frightening particularity. Its solidity and substance - its black sheen, its five asymmetrical corners, its immovable weight - attest to conviction and a kind of interior truth. (Baxter, pp. 3-4)

The bizarre craft is therefore focused upon enveloping the spectator in what might be called the short story moment:

He sat alone in the darkened corner of the tavern, a small object before him on the age-worn table. 'It is my purpose,' he said, 'my burden, rather, to tell this story. I have carried this thing with me now for a dozen years and, when I die, it will become someone else's burden because its story must be told. It must never be allowed to be forgotten. I have watched you, does that make you uncomfortable? I have watched you all evening, and you are the one that must hear my story tonight.' He slid the object across the table towards me using only two fingers. The look in his eyes was a mixture of resignation and bewilderment, he hated this thing and yet seemed somehow mesmerized by its power, and I had no choice but to listen ...

It is a familiar opening; the beguiled stranger and beleaguered storyteller is at least as old as Coleridge's Rime of the Ancient Mariner. It represents the instant conflict between unwilling speaker, his hypnotized listener, and the unwantedyet-spellbinding thing. Now, suddenly, that fictional moment rouses to life in the real world, and the bizarrist's spectator is cast in the role of central character: Tonight you will bear witness to my extraordinary tale. 
This is the world of pure chance-where fate has pointed to one person who will be forever changed in a brief encounter with an item so very unusual and yet so possible. The object is suddenly the point of the encounter, the reason for the performer's existence. No more 'I just happened to leave the house this morning with a long rope, a short rope, and ....' Who now can say where the logic ends and fantasy begins? The bizarrist must play this well, earnestly. The story must ring true, as did Welles's Martian invasion; it must be likely and believable. It does not matter where or how he acquired this object so much as the fact that he has acquired it-in much the same way that Welles need not detail how Martian technology works, but only that it has arrived on our planet, so the Bizarrist must focus upon the truth of the moment rather than the varied (and improbable) coincidences that have led up to it. And his story simply must now unfold.

Magic was historically the province of priests, healers, supernatural beings, and other such Gnostics. With the advent of theatre, even as early as the sixteenth century, it migrated into an art form and entertainment. People, slowly at first but with increasing awareness, came to understand that magicians were performers merely pretending to harness unnatural powers, and soon magicians became classed with jugglers, rope walkers, contortionists, mathematical horses, perceptive pigs, and other 'natural wonders.'

By the late eighteenth century, magic found a comfortable home on the stage, and throughout the nineteenth and early twentieth centuries, the stage magician was minor theatrical royalty. From the time of Pinetti, through the rise of Robert-Houdin, Bosco, Anderson, the Herrmanns, the developments of Maskelyne, Cooke, Devant, up into the Great Age of Houdini and all of their compatriots, magic developed into a regularized and accepted entertainment form. The audience learned to anticipate spectacle and pretended miracles.

The contract was drawn up during this period that the magician would set out to deceive the audience while the audience, in its turn, would agree to be pleasurably misdirected. Where the actor asked his audience to 'believe for the evening that I am Hamlet,' the magician required them to 'accept for tonight that I have powers' and all were happy with that arrangement. It was all playacting and make-believe.

The real decline began, of course, with the devolution of Vaudeville. Magicians began rather desperately to hunt about for new performance outlets, and failed. In their failure, magic (once a central entertainment) lost all touch with its own society. The art form stagnated, failed to reinvent itself, and became at last the 
province of self-mockery ('I learned this trick from that famous old Chinese magician Foo Ling $Y u^{\prime}$ ). Magicians themselves became frozen in time, relics still dressing in the eveningwear of a bygone age until today it is common to see eight-yearolds, bedecked in cape and cheap felt top hat, waving white-tipped sticks whilst making 'magic.'

Cinema is currently on the same mistaken trajectory that killed magic. The spectacle of 1950s epic film has already degenerated to where legions of moviegoers are jaded to ever-expanding attempts to create bigger and better CGI, 3D-driven extravaganzas, and movies that would have utterly devastated patrons fifty (or even fifteen) years ago. The cinema audience is becoming jaundiced to computer-enhanced effects, as the theatre audience of the 1940s became tired of magic effects. As such, wonder does not inhabit the local multiplex.

With cinema becoming bigger and louder, the Bizarrist seeks to present what is small and quiet-and consequently more beguiling: a bell in a still room, a darkening night with the beginnings of a storm gently rattling at the window; a story told well and with utter conviction; a departed soul wishing to make contact: this can be riveting. Why? Because it is different. In an entertainment matrix full of noise and spectacle, the silent curl of smoke from a candle's dying wick will, when properly situated within a tale, arrest the attention because it is fundamental, particular and primal. It is tangible, palpable, and immediate, and, because it speaks directly to the spectator, alive and alert, rather than through some electronic device, it is real.

Real is different to the 'virtual world' generation. The immediacy of such a presentation goes far beyond the rapid-access of info-glut defining modern concepts of normalcy.

Bizarre magic has not merely distanced itself from this perceived dead-end of traditional prestidigitation but is actually in the immediate process of rejecting the past 250 years of theatrical magic evolution. In essence, the Bizarre movement states that the magic fraternity should have never taken to the stage in the first place. It takes a new direction in magical performance, one that privately accepts its inherent theatricality but then presents deception as if it were truth. Because Bizarre magic quietly recognizes its theatricality, the impulse to entertain remains its driving force. However, unlike the theatrical experience, where the audience's side of the contract is a 'willing suspension of disbelief,' the presenter of the bizarre, paratheatrical experience positions the 
audience in a misty region wherein the spectator cannot fully know whether disbelief is even a wholly viable option.

Properly presented, the performance begins, continues, and ends without the audience ever quite knowing whether the performer is in earnest. This is entertaining in a new way - with a focus upon the illusion of reality. An alternate reality, to be sure, but that is the point of mystery. Herein the confraternity proposes to display for the edification (and sometimes terror) of its fellow human creature that ghosts walk, demons lurk, and ancient beliefs spark with truth before unwary eyes. The performer tells lies so truthfully, so convincingly, and so engagingly that the audience wishes to believe them as truth. Thus is created the illusion of reality.

Theatrically speaking, this is the difference between presentational and representational performance. These concepts are often misused and easily confused for one another, but to simplify them and be concise, the eastern theatrical tradition tends towards presentational performance. It seeks to display the idea of a character. This can be seen in Kabuki, Nō, Bunraku, Sanskrit, and Chinese Opera but it may be better understood by appeal to Western Opera. The performers seldom look in any realistic sense like the characters they present. All that matters is that the artist can perform the vocal part. Presentational performances are what might be described as 'large' or 'stagey' because they mean only to present the sense of the character while the focus is upon the artistry involved in that creation (dance, voice, or the like). The western mind has little tolerance for presentational performance, preferring to see more true-to-life representations of character. Hence, the western stages and screens are filled up with performers doing their level best to look and act believably like Hobbits, English kings, and Chicago mobsters.

The aim of bizarre performance is to become in a sense ultra-representational: the performer attempts to convince the audience not of the pretended reality of the performance situation but of its actual reality. The bizarre entertainment seeks to create a long-lasting impression that will haunt and artistically confabulate, creating and instilling a realistic memory spawned of a pretended story. Rather than going away merely 'engaged' or 'amused' by a performance, the audience of a bizarre presentation should go away intrigued, informed, and in a receptive mood to reevaluate their established notions of The Real.

But all of this only begs the important question: Why would someone want to see a magic trick? There's a simple question. The average persons on the street rates 
magic tricks at about the same entertainment level with long elevator rides. Oh god, they cringe, not a bloody magician!

The theatrical magician must, therefore, always begin with an uphill climb. The audience inwardly groans at the very thought of him, and he must win them over with an engaging personality (most important!), a well-conceived routine or act, and some effects that are truly effective. If he succeeds in this, his audience will enjoy the experience and consider him to be a cut above the runof-the-mill magician. In essence, he wins them over to his performance but not to the art of magic. And, so, the next magician will have to make that same uphill climb.

A Bizarre magician may avoid the climb altogether because his first weapon is defamiliarity. The audience does not at once recognize him as a magician. They may suspect it, but he never gives them a chance to become wary. No coin flourishing or card spreading. He launches immediately into a fascinating exploration of some artifact that really looks worth the examining. This doesn't appear to be a magic act. This is something else. A storyteller, perhaps-or perhaps a genuine examination of a genuine relic.

Defamiliarization is what Freud used in his consulting room. Recognizing that the patient may be uncomfortable talking to the doctor, Freud had a collection of antique figurines on his desk. He would ask his patient to pick one out and address her concerns to the one that made her feel most comfortable. Of course, the doctor listened in. In the same way, the bizarrist deflects onto an interesting curio all of the spectator's wariness about magicians. Because the item is something the spectator takes pleasure in considering, and because the tale surrounding it is engaging, the magic part of the presentation sneaks in through the back door (psychologically speaking), and the spectator is blind-sided by an effect-startled by the unexpected.

The Russian school of formalism called it ostranenie, and it is the attempt in literature to make the familiar appear strange and the common uncommon. 'Habit is the enemy of art' cry the Russians, quite correctly. Words become poetry when they force the beholder to see and experience what she would otherwise only accept. This is precisely how Bizarre magic avoids the pitfalls common to the traditional magician. The audience expects, and thereby accepts, that a magician will attempt to deceive them with a trick. When the magician succeeds, he has done nothing beyond the expected and the accepted, and, consequently, the experience is not particularly noteworthy; though it may certainly be amusing, it is hardly memorable. Hence, a magician who fails is 
often more fun to watch than one that succeeds because only in failure does he succeed in performing something unexpected.

When, however, the magician comes clothed in the weeds of the storyteller, with nary a sponge bunny in sight, the audience no longer knows what to expect. They accept that a storyteller will enchant them with words, and this is what they begin to expect. The ultimate experience is thereby defamiliarized. 'This is not a magic trick', the audience imagines, and so they come to perceive the magic with new eyes: eyes with which they are suddenly forced to see bewildering events that compel them to experience the moment beyond their accepted expectation.

Lulled into the belief that they are potentially experiencing a genuine occurrence, they accept those 'realities' of the storyteller and are suddenly and unexpectedly startled by the now-defamiliarized experience of the concealed magic within the story. In essence, this is magic pinpointed to work upon the audience alone. The society of magic can never experience the moment properly, for it will always expect to see an effect somewhere in the storytelling. Magicians can never alter those expectations or un-see the theatrical experience because they must by necessity know that they are watching a camouflaged magic performance. The audience, however, is in a different situation. The storyteller's clothing is an effective disguise, and the magician hidden beneath will work what now appears to be a real miracle upon the minds of his spectators. The story, therefore, absolutely must be worth the hearing.

\section{REFERENCES}

Baxter, Charles. The Art of Subtext: Beyond Plot. $3^{\text {rd }}$ ed. St. Paul: Graywolf Press, 2007

Berghahn, Daniella. Keynote address. "The Loss of Wide-Eyed Wonder? Recuperating the Exotic in Transnational European Cinema". ECREA Conference: European Cinemas, Intercultural Meetings. Royal Holloway, University of London, November 2015.

Gould, Christopher. Lecture delivered via Skype to the East Coast Spirit

Conference (III); Myrtle Beach, SC, January 2017.

Landman, Todd. Metaphysical Magic. Lulu imprint, 2010. 
Maskelyne, Nevil and Devant, David. Our Magic. E.P. Dutton \& Co. 1911.

Professor BC. Phasmology. ToL Press, 2016.

Thompson, Michael Guy. The Truth About Freud's Technique: The Encounter With the Real (Psychoanalytic Crosscurrents). New York: NYU Press, 1995.

\section{CONTRIBUTOR DETAILS}

Brian Jay Corrigan is senior professor of Renaissance literature at his university, general editor of The Compendium of Renaissance Drama (cord.ung.edu) an award-winning novelist, and proponent of the art of Bizarre Magic. Better known in the Bizarre community as Professor BC, Corrigan is a performer, philosopher, and creator of Bizarre magic whose creations include Doppelgänger, Phantoms, GH*ST, AES GOETIA, and The Resurrection Cemetery Gate Key among many others. He is the author of Phasmology, the Art of Paratheatrical Performance. Corrigan is an honorary Lifetime Member of Psycrets, The British Society of Mystery Entertainers, and has twice been inducted into Bizarre magic's Légion d'Horreur (Australia) as well as winning first place for his creations, Spectre and The Faerie Shilling, in international competition. Corrigan is currently at work on a biography of famed ghost-story writer M. R. James. He lives on a mountain above Atlanta, Georgia with his wife, Damaris, and their cats, dogs, and horses. 